\title{
Oil Shocks and the Excise Duty Tax in a DSGE Model Setting
}

\author{
Črt Lenarčič*
}

\begin{abstract}
This paper sets up a small open economy general equilibrium model operating in a monetary union. Exogenous oil shocks that hit the modelled economy are alleviated by introducing a pro-cyclical excise duty tax rule on oil prices. It provides a model-based theoretical background for studying a fiscal response of curbing the negative effects of volatile global oil prices on inflation. Against this backdrop, we estimate the key parameters of the DSGE model and simulate different responses of the fiscal policy tax rule, based on different values of the responsiveness of the excise duty parameter.
\end{abstract}

Keywords: Oil shocks; fiscal policy tax rule; DSGE model; inflation

JEL Classification: E31, E32, E62

\section{Introduction}

Oil prices had always been a hot topic amongst policy makers as well as entrepreneurs and households. Fluctuations in oil prices have big effect on the economies and their monetary (and fiscal) policy activities as they can substantially affect the inflation rates and real output. Despite the importance of the oil-price shocks declined in the post1990 period, oil prices have risen in years following the outbreak of the financial crisis in the United States and the European Union. Only recently as prospects of a possible China cool-down in the economic activity forced oil prices to decline drastically and making new ground for further oil-shocks in the future. From the policy makers' perspective, it is therefore essential to tackle this problem efficiently. In order to that, monetary authorities are using complex dynamic macro models, such as DSGE models, trying to predict possible economy outcomes during oil-shock periods.

\footnotetext{
* Črt Lenarčič is at Banka Slovenije, Ljubljana, Slovenia.

The views presented herein are those of the authors and do not necessarily represent the official views of Banka Slovenije or of the Eurosystem.
} 
Several studies have investigated the effect of oil-price shocks on the economy, and the role played by the monetary policy. The wide fluctuations in oil prices in recent years have spur new research agendas trying to assess the effects of oil price shocks. Despite the relatively small share in the overall consumption basket, these shocks can significantly affect households and firms' decisions, the oil prices are quite volatile in comparison to other HICP components. In general, latest studies have used models to decompose direct effects of oil-price shocks on output and other economic variables, from those generated by the endogenous monetary policy response (Hamilton 1983; Bernanke, Gertler and Watson 1997; Leduc and Sill 2001; Hamilton and Herrera 2004; Herrera and Pesavento 2007; Lippi and Nobili 2009; Anzuini, Pagano and Pisani 2013). However, studies applying the reduced-form coefficients in VAR-types of models make it difficult to disentangle the contribution of the monetary policy, and thus study oil shock effects in more detail. This can be done by developing more complex macroeconomic models, a characteristic that DSGE models have. Against this backdrop, a small open economy DSGE model is developed, following the works of Medina and Soto (2005), Hongzhi (2010), and Forni, Gerali, Notarpietro and Pisani (2012), where the difference between oil and non-oil goods explicitly modelled. Consistently with empirical evidence, the assumption is that crude oil is imported from the rest of the world by oil-importing firms and sold to domestic households.

The contribution of the paper is the following. We follow a Medina and Soto (2005) type of model setting, but we refrain from it in two important aspects. First, we extend the model with a complete government spending block that provides a background for the implementation of the excise duty rule 1 . Doing this, the government can offset the negative effects of oil shocks on inflation.

And second, we try to fill the gap by studying the effects of oil shocks on a small open economy model integrated in a single monetary union, the euro area. Slovenia is a typical example based on the above-mentioned characteristics. It has no oil-producing capacities; therefore all of its oil products are imported. It is strongly affected by the fluctuations in world prices of oil. Based on this, we estimate a small open economy dynamic stochastic general equilibrium model.

The structure of the model follows a standard New Keynesian framework with frictions such as Calvo pricing (1983) and Calvo wage setting equation introduced by Erceg, Henderson and Levin (2000), and Christiano, Eichenbaum and Evans (2005). For the purpose of simulating a single monetary union the euro area interest rate is modelled in a Taylor type rule setting (Taylor 1993) with the addition of a risk-premium for the home interest rate that allows for deviations of the domestic interest rate from the euro area interest rate (Schmitt-Grohé and Uribe 2003). We assume that the domestic economy's size is negligible, so its specific economic fluctuations have no influence on other euro area macroeconomic aggregates, such as the euro area GDP and prices. 
As commonly done in the DSGE literature, a number of parameters are calibrated from the outset, and are not included in the estimation process. However, some key structural parameters of the modelled economy are estimated following a Bayesian approach as in Smets and Wouters (2003), Adolfson et al. (2005), and Christoffel, Coenen and Warne (2008). With the estimated model we simulate how would main macroeconomic variables respond primarily to an oil-price shock.

The results show that global oil-price shocks can still have large effects on the Slovene economy. The fiscal policy authority has the power to offset the pressure that the oil price shocks have onto the overall inflation by counter-cyclically regulate the excise duty tax rate on oil products. However, this comes at a cost. Decreased tax income decreases government spending and increases the budget deficit, if the government chooses not to decrease its spending one to one with the decrease in tax income.

The rest of the paper is organised as follows. Section 2 presents a concise structure of the DSGE model. Section 3 discusses the calibration, while Section 4 presents the results of the estimation. Section 5 provides impulse response functions and historical decomposition. Section 6 concludes.

\section{Model}

\section{Households}

In the economy there is a continuum of households indexed by $i \in(0,1)$. In time $t$ a household gains utility from consumption, $C_{t}(i)$, and leisure, $1-L_{t}(i)$. The $i$-th household's therefore follows its lifetime utility function:

$$
E_{0} \sum_{t=0}^{\infty} \beta^{t}\left[\ln \left(C_{t}(i)-h C_{t-1}(i)\right)-\frac{\xi_{t}^{l}}{1+\varpi} L_{t}^{1+\varpi}(i)\right]
$$

where and present consumption and quantity of work effort of a particular household. The parameter Parameter $0<\beta<1$ is the discount factor of household. We assume that households value the current consumption more than the future one. The parameter $0<\bar{\sigma}<\infty$ is the inverse of the elasticity of work effort with respect to marginal disutility of labour (Frisch elasticity parameter). We allow for habit persistence in preferences by defining $h C_{t-1}(\mathrm{i})$, where $0<h<1$ determines the degree of habit persistence. Variable is denoted as labour supply shock ${ }^{2}$. 
We assume that households are the same, so $C_{t}(i)=C_{t}$ holds. The consumption bundle of the $i$-th household is given by the following function

$$
C_{t}=\left[\omega_{O C}^{\frac{1}{v_{O C}}}\left(O_{t}^{C}\right)^{\frac{v_{O C}-1}{v_{O C}}}+\left(1-\omega_{O C}\right)\left(C_{t}^{C}\right)^{\frac{v_{O C}-1}{v_{O C}}}\right]^{\frac{v_{O C}}{v_{O C}-1}}
$$

where the variable $O_{t}^{C}$ represents oil consumption, and the variable $C_{t}^{C}$ represents the consumption of every other good. The parameter $v_{O C}$ is the elasticity of substitution between oil and non-oil consumption, while the parameter $\omega_{O C}$ is the share of oil in the overall consumption bundle. Further on, the consumption of every other good, $C_{t}^{C}$, or the so-called core consumption good, again represents an additional consumption bundle that is made of domestically produced goods and foreign imported goods. The core consumption bundle is then given by

$$
C_{t}^{C}=\left[\omega_{F H}^{\frac{1}{v_{F H}}}\left(C_{t}^{F}\right)^{\frac{v_{F H}-1}{v_{F H}}}+\left(1-\omega_{F H}\right)\left(C_{t}^{H}\right)^{\frac{v_{F H}-1}{v_{F H}}}\right]^{\frac{v_{F H}}{v_{F H}-1}}
$$

where the parameter $v_{F H}$ is the elasticity of substitution between imported and domestic good, while the parameter $\omega_{F H}$ is the share of imported goods in the core consumption bundle. Now we have all the ingredients to define demand functions for each type of good. The demands for oil and core consumption good are defined as

$$
C_{t}^{C}=\left(1-\omega_{O C}\right)\left(\frac{P_{t}^{C}}{P_{t}}\right)^{-v_{O C}} C_{t}
$$

and

$$
O_{t}^{C}=\omega_{O C}\left(\frac{P_{t}^{O}}{P_{t}}\right)^{-v_{O C}} C_{t}
$$

The demands for foreign and home good are defined as

$$
C_{t}^{F}=\omega_{F H}\left(\frac{P_{t}^{F}}{P_{t}^{C}}\right)^{-v_{F H}} C_{t}^{C}
$$


and

$$
C_{t}^{H}=\left(1-\omega_{F H}\right)\left(\frac{P_{t}^{H}}{P_{t}^{C}}\right)^{-v_{F H}} C_{t}^{C}
$$

where $P_{t}, P_{t}^{O}, P_{t}^{C}, P_{t}^{F}$ and $P_{t}^{H}$ are prices for the respected consumption goods. Based on the consumption bundles we can define the overall inflation, $P_{t}$, as

$$
P_{t}=\left[\omega_{O C}\left(P_{t}^{O}\right)^{1-v_{O C}}+\left(1-\omega_{O C}\right)\left(P_{t}^{C}\right)^{1-v_{O C}}\right]^{\frac{1}{1-v_{O C}}}
$$

Analogous to the overall inflation, the core inflation, $P_{t}^{C}$, is given by

$$
P_{t}^{C}=\left[\omega_{F H}\left(P_{t}^{F}\right)^{1-v_{F H}}+\left(1-\omega_{F H}\right)\left(P_{t}^{H}\right)^{1-v_{F H}}\right]^{\frac{1}{1-v_{F H}}}
$$

Since households are identical ex ante, they face the same budget constraint in each period given by the expression:

$$
\begin{gathered}
\frac{B_{t}(i)}{R_{t}}+\frac{B_{t}^{*}(i)}{R_{t}^{*} \Theta\left(\frac{B_{t}^{*}}{P_{t}^{X} X_{t}}\right)}= \\
B_{t-1}(i)+B_{t-1}^{*}(i)+\left(1-\tau_{L}\right) W_{t}(i) L_{t}(i)+\Pi_{t}(i)+T R_{t}(i)-\left(1+\tau_{t}^{C}\right) P_{t} C_{t}(i)
\end{gathered}
$$

$B_{t}^{*}$ denotes the holdings of one-period foreign (euro area) riskless bonds, while $B_{t}$ denotes the holdings of one-period domestic bonds that can be issued by the home government. The nominal interest rates of bonds prevail at the time when the decision is taken, by $R_{t}^{*}$ and $R_{t}$, respectively. Assuming the existence of a full set of contingent bonds ensures that consumption of all households is the same, independently of the labour income they receive each period. The variable denotes dividend profits of hoseholds from domestic firms. The variable $W_{t}$ is the nominal wage set by a household, while $T R_{t}$ is the capita lump-sum net transfers from the government. The parameter $\tau_{L}$ is the income tax rate and is assumed to be fixed over time. On the opposite side we assume a time-varying value added tax on consumption, $\tau_{t^{*}}^{{ }^{*}}$ Each time a domestic household borrows from abroad it must pay a premium over the international price of external bonds, denoted as $\Theta\left(B_{t}^{*} / P_{t}^{X} X_{t}\right)$ (Schmitt-Grohé and Uribe, 2003). In comparison to the Medina and Soto (2005) the parametrization of the function $\Theta$ depends only of risk premium and not the nominal exchange rate as well. This is due to the fact, that we build a small open economy model operating in a monetary union. In the steady state, for $\Theta$ holds 


$$
\Theta\left(\frac{B^{*}}{P^{X} X}\right)=\bar{\Theta}, \text { and } \frac{\Theta^{\prime}\left(\frac{B^{*}}{P^{X} X}\right)}{\Theta\left(\frac{B^{*}}{P^{X} X}\right)} \frac{B^{*}}{P^{X} X}=\varrho
$$

The parameter $\varrho$ is the elasticity parameter of the upward sloping supply of international funds, while $P^{X} X$ is the steady state value of exports and $B^{*}$ stands for the steady state for net foreign asset position.

Labour is differentiated over households meaning that each household is a monopoly supplier of a distinct variety of labour service, which implies that the households can determine their own wage (Erceg, Henderson and Levin 2000; Christiano, Eichenbaum and Evans, 2005). Applying the wage stickiness à la Calvo households sell their labour service to a firm, which then transforms the labour service into a homogeneous input good $L$ using the Dixit-Stiglitz aggregator

$$
L_{t}=\left[\int_{0}^{1} L_{t}(i)^{\frac{v_{L}-1}{v_{L}}}\right]^{\frac{v_{L}}{\nu_{L}-1}}
$$

where the parameter $v_{L}$ represents the elasticity of substitution between varieties of labour. Firms take the input price of the -th differentiated labour service as given, as well as the price of the homogeneous labour. The demand for labour is therefore defined as

$$
L_{t}(i)=\left[\frac{W_{t}(i)}{W_{t}}\right]^{-v_{L}} L_{t}
$$

where $W_{t}(i)$ is the -th household's wage, and $W_{t}$ is the aggregate wage that is given by

$$
W_{t}=\left[\int_{0}^{1} W_{t}(i)^{1-v_{L}}\right]^{\frac{1}{1-v_{L}}}
$$

Since the households are a monopoly supplier of labour services, then each household also has some decision power over the wage it charges, $W_{t}(i)$. We assume that not all households can set its wages optimally in every period. A household receives a random wage-change signal at a constant probability, $1-\alpha_{L}$. In this case the household can set a new optimal wage, $W_{o p t}^{t}(i)$. With probability, $\alpha_{L}$, other households update their wage by indexation to the current numerarie inflation rate target, $\bar{\pi}_{t}$, and previous period numeraire inflation rate, $\pi_{t}^{n u m}=P_{t}^{n u m} / P_{t-1}^{n u m}$. The household that cannot re-optimize in period $t$ will passively set its wage according to 


$$
W_{t+k}(i)=\left(\pi_{t}^{n u m} \ldots \pi_{t+k-1}^{n u m}\right)^{\varphi_{L}}\left(\bar{\pi}_{t+1} \ldots \bar{\pi}_{t+k}\right)^{1-\varphi_{L}} W_{t}(i)
$$

where the parameter $0<\varphi_{L}<1$ is the degree of wage indexation to the previous period inflation rate. On the other hand, the households that are able to re-optimize their wage, they face the following maximization problem

$$
\begin{gathered}
E_{t}\left\{\sum _ { k = 0 } ^ { \infty } \alpha _ { L } { } ^ { k } \Lambda _ { t , t + k } \left[\frac{W_{t+k}^{\text {opt }}(i)\left(\pi_{t}^{\text {num }} \ldots \pi_{t+k-1}^{\text {num }}\right)^{\varphi_{L}}\left(\bar{\pi}_{t+1} \ldots \bar{\pi}_{t+k}\right)^{1-\varphi_{L}}}{P_{t+k}^{\text {num }}}\right.\right. \\
\left.\left.\quad-\xi_{t}\left(L_{t+k}(i)\right)^{\Phi}\left(C_{t+k} h C_{t+k-1}\right)\right] L_{t+k}(i)\right\}
\end{gathered}
$$

where the expression $\Lambda_{t, t+k}=\beta\left(C_{t}-h C_{t-1}\right) /\left(C_{t+k}-h C_{t+k-1}\right)$ is discount factor of the relative consumption between the period and period $t+k$.

\section{Firms}

\section{Domestic Good Firms}

We have a continuum of representative domestic good firms indexed by and are operating in a monopolistic competition environment. They maximize their profits by choosing their optimal Calvo (1983) price of its product variety $j$. The corresponding demand and the technology is given by

$$
Y_{t}^{H}(j)=Z_{t}^{H}\left[\omega_{O L}^{\frac{1}{v_{O L}}}\left(O_{t}^{H}(j)\right)^{\frac{v_{O L}-1}{v_{O L}}}+\left(1-\omega_{O L}\right)\left(L_{t}^{H}(j)\right)^{\frac{v_{O L}-1}{v_{O L}}}\right]
$$

where $Y_{t}^{H}$ is the quantity of a particular variety of home good, while $Z_{t}^{H}$ is a productivity shock in the home goods sector and is the same for all firms with the exogenous innovation $\varepsilon_{t}^{A}$. The variables $O_{t}^{H}(j)$ and $L_{t}^{H}(j)$ are the oil input and labour input in the production process of a particular variety of home produced good. The parameter represenents the share of oil in the production process, while the parameter $\omega_{O L}$ is the elasticity of substitution between the oil and labour inputs.

From the first order condition, we can obtain the optimal mix of both production inputs, so that

$$
\frac{1-\omega_{O L}}{\omega_{O L}} \frac{O_{t}^{H}(j)}{L_{t}^{H}(j)}=\left(\frac{W_{t}}{P_{t}^{O}}\right)^{v_{O L}}
$$


Based on the minimization problem defined in the equation (17) we get the expression for the nominal marginal costs that depend on the prices of both production inputs and the productivity process

$$
M C_{t}^{H}=\frac{1}{Z_{t}^{H}}\left[\omega_{O L}\left(P_{t}^{O}\right)^{1-v_{O L}}+\left(1-\omega_{O L}\right)\left(W_{t}\right)^{1-v_{O L}}\right]^{\frac{1}{1-v_{O L}}}
$$

Similarly as in the labour market sector, we assume that a fraction of firms $\left(1-\alpha_{H}\right)$ can reset their prices while the others $\alpha_{H}$ set their price accordingly to the indexation rule (Calvo, 1983). If a firm receives the price-changing signal then it maximizes the optimal price $P_{t}^{H, o p t}$

$$
E_{t} \sum_{k=0}^{\infty}\left(\beta \alpha_{H}\right)^{k} \Lambda_{t, t+k}\left[\frac{P_{t+k}^{H, o p t}(j)\left(\pi_{t}^{H} \ldots \pi_{t+k-1}^{H}\right)^{\varphi_{H}}\left(\bar{\pi}_{t+1} \ldots \bar{\pi}_{t+k}\right)^{1-\varphi_{H}}-M C_{t+k}^{H}}{P_{t+k}^{n u m}} Y_{t+k}^{H}(j)\right]
$$

subject to the demand of the variety of $j$ product

$$
C_{t}^{H}(j)=\left[\frac{P_{t}^{H}(i)}{P_{t}^{H}}\right]^{-v_{H}}\left(C_{t}^{H}+C_{t}^{H, *}\right)
$$

where the parameter $v_{H}$ denotes the price elasticity of the demand of a variety of $j$. The variable $C_{t}^{H, *}$ is the foreign demand for home goods. The inflation variable $\pi_{t}^{H}$ is defined by home good prices $P_{t}^{H} / P_{t-1}^{H}$. The other firms set their price accordingly to the passive indexation rule

$$
P_{t+k}^{H}(j)=\left(\pi_{t}^{H} \ldots \pi_{t+k-1}^{H}\right)^{\varphi_{H}}\left(\bar{\pi}_{t+1} \ldots \bar{\pi}_{t+k}\right)^{1-\varphi_{H}} P_{t}^{H}(i)
$$

where $0<\varphi_{H}<1$ is the inflation indexation parameter. In the end we specify the profits that a -th firm follows

$$
\Pi_{t}(j)=P_{t}^{H}(i) Y_{t}^{H}(i)-P_{t}^{O} O_{t}^{H}(j)-W_{t} L_{t}^{H}(j)
$$

Foreign Economy

The foreign economy consists of the demand for home produced goods ${ }^{4}$

$$
C_{t}^{H,{ }^{*}}=\omega_{F H, *}\left[\frac{P_{t}^{H,{ }^{*}}}{P_{t}^{F, *}}\right]^{-v_{H, *}} C_{t}^{*}
$$


where the parameter $\omega_{H F}$ represents the share of the domestic intermediate goods in the consumption basket abroad, while $v_{H, *}$ is the price elasticity of demand. The assumption is that domestic firms do not price discriminate across markets. Consequently the law of one price holds, so that $P_{t}^{H,{ }^{*}}=P_{t}^{H}$. Since the modelled small open economy operates in a monetary union the real exchange rate is just a relative price between foreign and home price index, so that

$$
R E R_{t} \equiv \frac{P_{t}^{F{ }^{*}}}{P_{t}^{n u m}}
$$

In the real exchange rate we assume that the foreign consumption bundle does not include oil consumption, and that the size of $\omega_{F H, *}$ is too small to affect the foreign inflation. Foreign inflation, however, is subject to a $A R(1)$ process with the exogenous innovation $\varepsilon_{t}^{P^{*}}$. Based on this we have to define the relative domestic price of oil. The expression is given by

$$
\frac{P_{t}^{O}}{P_{t}^{\text {num }}}=R E R_{t} \frac{P_{t}^{O,{ }^{*}}}{P_{t}^{F, *}}\left(1+\tau_{t}^{O}\right)
$$

The variable $\tau_{t}^{O}$ corresponds to deviations from the law of one price in the relative oil price, due to excise duty tax on oil prices. Additionally the domestic relative oil price depends on the real exchange rate and the foreign relative oil price. The foreign price of oil $P_{t}^{O, *}$ is subject to a $A R(1)$ process with $\varepsilon_{t}^{P_{O, *}}$ being the exogenous innovation.

\section{Government}

The fiscal block follows the Almeida (2009) and Almeida et al. (2011) papers, but we add the extension of an excise duty tax rule. The government's activity is based on the acquisition of the government's consumption good, $G_{t}$, payment of debt, $\left(R_{t-1}-1\right) B_{t}$, and household transfers, $T R_{t}$. On the other side, the government finances itself by collecting value added tax, excise duty tax on oil consumption and income tax, $\tau_{t}^{C} P_{t} C_{t}+\tau_{t}^{O} P_{t}^{O} O_{t}+\tau_{L} \int_{0}^{1} W_{t}(i) L_{t}(i) \mathrm{di}$, and debt issuance, $B_{t}$. The variables $G_{t}$ and $\tau_{t}^{C}$ are modelled as $A R(1)$ processes with $\varepsilon_{t}^{G}$ and $\varepsilon_{t}^{\tau C}$ being the respected exogenous innovations. Government spending $G_{t}$ also depends on $\tau_{t}^{0}$, so that

$$
\tau_{t}^{C} P_{t} C_{t}+\tau_{t}^{O} P_{t}^{O} O_{t}+\tau_{L} \int_{0}^{1} W_{t}(i) L_{t}(i) \mathrm{di}
$$

The intuition behind the equation (27) is to introduce the trade-off the government makes when it tries to put less pressure on the inflation as the oil shock occurs 
with respect to a decrease in its spending. Continuing, we get the government's primary deficit

$$
d e f_{t}^{p r i m}=P_{t} G_{t}+T R_{t}-\tau_{t}^{C} P_{t} C_{t}-\tau_{t}^{O} P_{t}^{O} O_{t}-\tau_{L} \int_{0}^{1} W_{t}(i) L_{t}(i) \mathrm{di}
$$

We allow for the excise duty tax on oil consumption $\tau_{t}^{0}$ to vary over time so that

$$
\tau_{t}^{O}=\rho_{\tau} \tau_{t-1}^{O}-\left(1-\rho_{\tau}\right) \gamma_{O} \bar{\pi}_{t}^{O{ }^{*}}+\varepsilon_{t}^{\tau_{O}}
$$

This feature helps the fiscal part of the economy to curb the effects of the dynamics of global oil prices, $\bar{\pi}_{t}^{O,{ }^{*}}=P_{t}^{O,{ }^{*}} / P_{t}^{n u m}$, on the domestic economy via excise duty tax rule. Something similar was done by Jakab, Baksa and Benk (2010). However, they introduce a general tax rule based on the GDP gap. The idea behind it is that when oil prices rise the government decreases the excise duty on oil consumption in order to decrease the price pressure on the firms and households. On the other hand the lower excise duty tax income decreases the government spending and thus decreases the aggregate output. Adding interest outlays, we get the government's total deficit

$$
d e f_{t}^{t o t}=d e f_{t}^{\text {prim }}+\left(R_{t-1}-1\right) B_{t}
$$

The government's budget constraint is defined by equalling government's resources and expenditures, such that

$$
B_{t+1}+\tau_{t}^{C} P_{t} C_{t}+\tau_{t}^{O} P_{t}^{O} O_{t}+\tau_{L} \int_{0}^{1} W_{t}(i) L_{t}(i) \mathrm{di}=P_{t} G_{t}+R_{t-1} B_{t}+T R_{t}
$$

such that

$$
B_{t+1}=B_{t}+d e f_{t}^{t o t}
$$

In order to prevent explosiveness of the debt path a fiscal has to be imposed by restricting $D E f_{t}^{\text {prim }}$ with endogenously adjusting $T R_{t}$ and ensuring that the debt-to-GDP ratio converges to a stable long-term value. The rule is given by

$$
\frac{d e f_{t}^{\text {prim }}}{\widehat{g d p}}=-v_{g}\left(\frac{B_{t+1}}{\widehat{g d p}}-\left(\overline{\frac{B}{\widehat{g d p}}}\right)\right)
$$

where $\widehat{B / \widehat{g d p}}$ stands for the target value of the stationary debt-to-GDP ratio. The parameter $v_{g}$ is the government's response parameter to the compliance of debt-to- 
GDP ratio. The idea behind the fiscal rule is that whenever the debt-to-GDP ratio rises above the target value, the transfers to households, $T R_{t}$, automatically decrease in order to reduce the government's expenditures and later on its deficit.

\section{Monetary Policy}

Monetary policy interest rate is modelled as a Taylor rule (Taylor, 1993) and determines the interest rate for both economies operating in the monetary union

$$
R_{t}^{*}=\rho_{R} R_{t-1}^{*}+\left(1-\rho_{R}\right)\left(\gamma_{\pi} \pi_{t}^{*}+\gamma_{y} C_{t}^{*}\right)+\varepsilon_{t}^{M P}
$$

$\varepsilon_{t}^{M P}$ represents an exogenous monetary policy shock. For the output gap we assume that foreign demand $C_{t}^{*}$ is large enough in comparison to the Slovene economy, so that the Slovene aggregate production would significantly affect both economies together. Foreign demand $C_{t}^{*}$ and inflation, $\pi_{t}^{*}$, is assumed to be exogenous $A R(1)$ processes with innovations $\varepsilon_{t}^{Y_{F}}$ and $\varepsilon_{t}^{P}$, respectively.

\section{Market Clearing}

In the composite good market, supply of domestically produced good must satisfy the all types of demand

$$
Y_{t}^{H}=C_{t}^{H}+C_{t}^{H,{ }^{*}}+G_{t}
$$

The labour market implies that demand equals supply of labour

$$
L_{t}=L_{t}^{H}
$$

From the aggregate budget constraint of households we obtain an expression for the aggregate accumulation of international bonds

$$
\frac{B_{t}^{*}}{R_{t}^{*} \Theta\left(\frac{B_{t}^{*}}{P_{t}^{X} X_{t}}\right) P_{t}^{\text {num }}}=\frac{B_{t-1}^{*}}{P_{t}^{\text {num }}}+\frac{P_{t}^{X}}{P_{t}^{\text {num }}} X_{t}-\frac{P_{t}^{M}}{P_{t}^{\text {num }}} M_{t}
$$

The total value of exports depends on the foreign demand for domestically produced goods

$$
\frac{P_{t}^{X}}{P_{t}^{\text {num }}} X_{t}=\frac{P_{t}^{H}}{P_{t}^{\text {num }}} C_{t}^{H, *}
$$


On the other hand the value of imports depends on the real exchange rate and the domestic demand for foreign goods and demand for oil and is given by

$$
\frac{P_{t}^{M}}{P_{t}^{\text {num }}} M_{t}=R E R_{t} C_{t}^{F}+\frac{P_{t}^{O, *}}{P_{t}^{\text {num }}} O_{t}
$$

where $O_{t}=O_{t}^{C}+O_{t}^{H}$ represents the total oil imports, comprised by household oil consumption and oil inputs in the home economy production process. We are left with the definition of the GDP, which is given then by

$$
\frac{P_{t}^{Y}}{P_{t}^{\text {num }}} Y_{t}=\frac{P_{t}}{P_{t}^{\text {num }}} C_{t}+\frac{P_{t}^{X}}{P_{t}^{\text {num }}} X_{t}-\frac{P_{t}^{M}}{P_{t}^{\text {num }}} M_{t}+\frac{P_{t}}{P_{t}^{\text {num }}} G_{t}
$$

\section{Calibration of the Model}

The key calibrated parameters are set with the intention of suiting the model as close as possible to the economy characteristics of interest - Slovenia, and at the same time are not of interest of the estimation process. The calibrated parameters are set according to already known empirical facts and national statistics data. The inverse of the elasticity of work effort (Frisch elasticity), $\varpi$, is set to 1 . The remaining parameters are: the discount factor, $\beta$, is set to 0.995 , while the degree of habit persistence is $h=0.85$. The target debt-to-GDP ratio, $\widehat{b} / \widehat{g d p}$, is set to 0.6 , which is in-line with the Maastricht criteria. The other macro-related parameters relate to long-term averages and are set accordingly to the data from the Statistical Office of Republic of Slovenia (SORS). Government spending relative to the GDP is set to $17 \%$, while net exports are set to $0.5 \%$. The import share of goods in the consumption basket, $\omega_{F H}$, takes the value of 0.5 , while the share of oil in the total consumption basket, $\omega_{O C}$, and the share of oil in the production process, $\omega_{O L}$, take the value of 0.06 . The Calvo wage parameter $\alpha_{H}$ is set to 0.875 , while the wage indexation parameter $\varphi_{H}$ is set to 0.5 . The elasticities of substitution between the same varieties of goods, $v_{H}$, and labour, $v_{L}$, are set to 11 . Since Slovenia is a small open economy operating in a monetary union (i.e. without a significant effect on the monetary policy decision), we set the inflation and output interest rate response parameters to $\gamma_{\pi}=1.5$ and $\gamma_{y}=0.1$ (Taylor rule parameters), close to Fourçans and Vranceanu (2004) estimated parameters for the euro area. 


\section{Estimation and Results}

In this subsection bayesian estimation results of the model are presented. The parameters of our interest are estimated with bayesian methods. Bayesian inference starts from setting out a prior distribution of the model's parameters, which were not calibrated. In more detail, the prior distribution describes the available information prior. Then we observe the available statistical data in order to update the information prior with Bayes theorem, and obtain the posterior distribution of the model's parameters. The dataset ${ }^{5}$ spanning from 2002Q1 to 2017Q3 in this process is comprised by Slovene quarterly data: real GDP, real government spending, employment, excise duty tax rate, core inflation and HICP inflation. We add quarterly time series for the euro area real GDP as well. The original statistical series are not stationary; therefore, the stationarity of the data has to be imposed first by log-differentiating and demeaning of the data. The data enters the model as percent deviation from the steady state. The Metropolis-Hastings MCMC algorithm is used with 1.000.000 steps and two sequential chains with the acceptance rate per chain at a rate of $33.6 \%$.

The results of the prior and posterior distribution of the estimated parameters and shocks are shown in Table 1. Looking at the estimation results, all the shocks are relatively persistent. The persistence parameters of shocks are denoted by parameters $\rho$. Their values are mostly estimated to be between 0.65 and 0.8 . While non of the shocks is excessively persistent, but are in-line with the existing literature (for example Forni et al., 2015; Smets and Wouters, 2003). The elasticities of substitution between oil and non-oil products, $v_{O C}$, and factors, $v_{O L}$, as expected exhibit low values, suggesting that oil is very inelastic. Inelasticity of oil is widely empirically documented (Miyazawa, 2009; Caldara, Cavallo and Iacoviello, 2016). What is more interesting is the estimate of the response parameter of excise duty tax rule, $\gamma_{o}$. It takes the value of 0.0964 . If we consider the persistence parameter of the excise duty tax rule, $\rho_{\tau}$, than by simple algebra we can conclude that the government's reaction to a 1 p.p. increase in global oil price, the excise duty tax rate decreases by 0.025 p.p.. More on the effects of oil shocks are presented in the next section where we analyse impulse response functions. 
Table 1: Prior and posterior distribution of the estimated parameters and shocks

\begin{tabular}{|c|c|c|c|c|c|c|}
\hline Parameter & Prior mode & Posterior mode & \multicolumn{2}{|c|}{ 90\% HPD interval } & Prior distribution & Posterior distribution \\
\hline$\gamma_{O}$ & 0.1000 & 0.0964 & 0.0499 & 0.1419 & beta & 0.0300 \\
\hline$\gamma_{G}$ & 0.1000 & 0.0929 & 0.0463 & 0.1371 & beta & 0.0300 \\
\hline$v_{F H}$ & 1.0000 & 0.8492 & 0.7044 & 0.9904 & gamma & 0.1000 \\
\hline$v_{O C}$ & 0.1000 & 0.0808 & 0.0419 & 0.1188 & gamma & 0.0300 \\
\hline$v_{O L}$ & 0.1000 & 0.0956 & 0.0495 & 0.1408 & gamma & 0.0300 \\
\hline$v_{F H, *}$ & 1.0000 & 0.6922 & 0.5629 & 0.8171 & gamma & 0.1000 \\
\hline$\varphi_{H}$ & 0.7500 & 0.1659 & 0.0949 & 0.2329 & beta & 0.1000 \\
\hline$\alpha_{H}$ & 0.7500 & 0.7263 & 0.6536 & 0.8021 & beta & 0.1000 \\
\hline$\rho_{P *}$ & 0.7500 & 0.7794 & 0.7213 & 0.8400 & beta & 0.0700 \\
\hline$\rho_{A}$ & 0.7500 & 0.7165 & 0.5623 & 0.8746 & beta & 0.1000 \\
\hline$\rho_{P_{O^{*}}}$ & 0.7500 & 0.6554 & 0.5002 & 0.8182 & beta & 0.1000 \\
\hline$\rho_{Y F}$ & 0.7500 & 0.7324 & 0.5745 & 0.8969 & beta & 0.1000 \\
\hline$\rho_{\tau_{o}}$ & 0.7500 & 0.7472 & 0.6024 & 0.8994 & beta & 0.1000 \\
\hline$\rho_{G}$ & 0.7500 & 0.7638 & 0.6188 & 0.9138 & beta & 0.1000 \\
\hline$\rho_{\tau_{C}}$ & 0.7500 & 0.7929 & 0.6508 & 0.9349 & beta & 0.1000 \\
\hline$\rho_{\rho}$ & 0.7500 & 0.6999 & 0.6947 & 0.7049 & beta & 0.1000 \\
\hline$\varepsilon_{M P}$ & 0.4000 & 0.4019 & 0.3226 & 0.4796 & inv. gamma & 0.1000 \\
\hline$\varepsilon_{P *}$ & 0.5000 & 0.1341 & 0.1148 & 0.1529 & inv. gamma & 0.2000 \\
\hline$\varepsilon_{A}$ & 0.7000 & 0.2147 & 0.1856 & 0.2432 & inv. gamma & 0.2000 \\
\hline$\varepsilon_{p_{O^{*}}}$ & 0.5000 & 0.3261 & 0.2205 & 0.4269 & inv. gamma & 0.2000 \\
\hline$\varepsilon_{Y_{F}}$ & 0.7000 & 0.2150 & 0.1863 & 0.2439 & inv. gamma & 0.2000 \\
\hline$\varepsilon_{\tau_{o}}$ & 0.5000 & 0.1192 & 0.1026 & 0.1352 & inv. gamma & 0.2000 \\
\hline$\varepsilon_{G}$ & 1.0000 & 0.4093 & 0.3547 & 0.4615 & inv. gamma & 0.2000 \\
\hline$\varepsilon_{\tau_{C}}$ & 1.0000 & 0.4185 & 0.3625 & 0.4712 & inv. gamma & 0.2000 \\
\hline
\end{tabular}

Source: author's calculations

\section{Impulse Response Functions and the Historical Shock Decomposition}

Figure 1 shows the contributions of the exogenous shocks onto the overall inflation through time. It is evident, that the inflation in Slovenia was influenced by global oil price dynamics. During the 2006-2008 boom period in Slovenia the global oil prices positively contributed to the Slovene inflation as the global economy was in a large upswing. The Slovene inflation drastically decreased as the global financial crisis hit at the second half of the 2008. As the global economy rebounded from the first wave of the global financial crisis, so did the global oil prices as the again positively contributed to the Slovene inflation in 2010 and the beginning of 2011. The 2011 and 2012 were 
characterised by the European sovereign crisis which affected the global demand for crude oil. This is shown by the negative contribution of oil shocks to the Slovene inflation. The negative contribution of oil shocks continued in the next years as the global oil prices continued to fall in 2014 and 2015. Only with the start of 2016 the pattern of positive oil price shocks to the Slovene inflation emerged again, which is in line with the global oil price dynamics as the emerging economies increased the global demand.

Figure 1: Historical decomposition of oil and other shocks on inflation (y-o-y growth rate in percent)

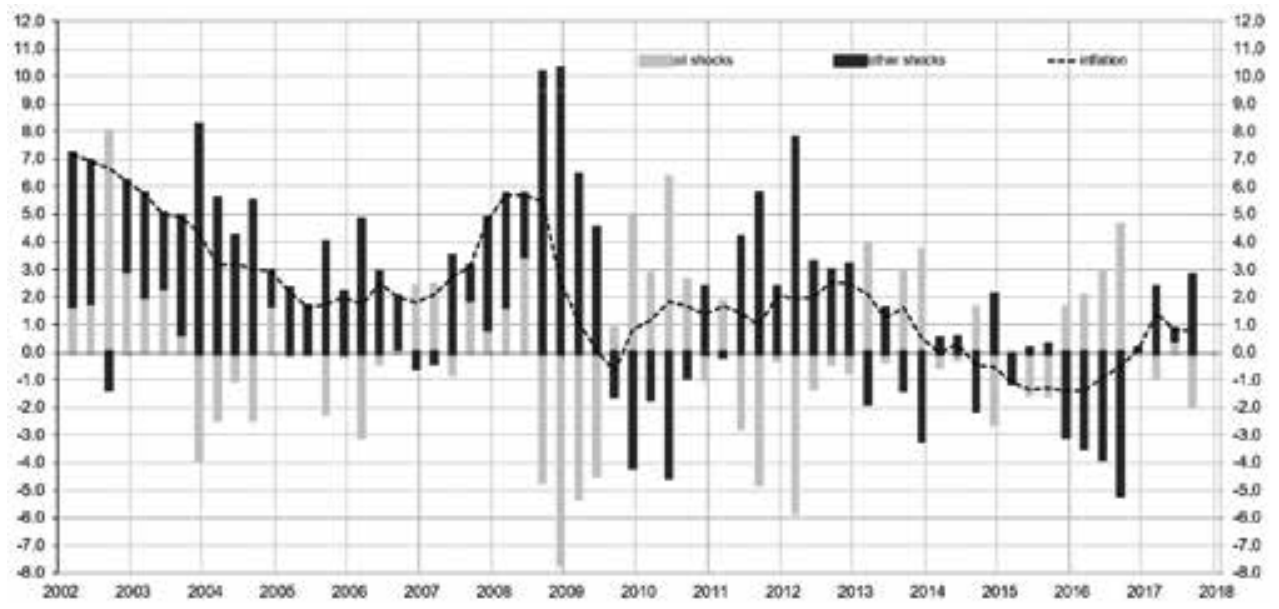

* Note: The contribution of other shocks are the sum of the initial values and shocks $\varepsilon_{M P}, \varepsilon_{P}, \varepsilon_{A}, \varepsilon_{p_{O, *}}, \varepsilon_{Y_{F}}, \varepsilon_{G}$, and $\varepsilon_{\tau_{C}}$.

Source: author's calculations

Going deeper into the analysis, the impulse response functions are depicted and assess how the key macroeconomic variables react to shocks induced to the modelled economy. In applied work namely, it is often of our interest to study the response of one variable to an exogenous impulse in another variable. Impulse response describes the evolution of the variable of interest along a specified time horizon after a shock in a given moment. The impulse responses of the exogenous shocks in the following figure depict a 30-period horizon. It is not, however, our objective to thoroughly analyse the simulated economy's impulse responses to all defined shocks, thus we limit the analysis to the response of macroeconomic variables only to the oil price shock and the shock to the tax rate of the excise duty on energy products.

According to our model, it seems that foreign oil price shocks can play a significant role in driving the macroeconomic dynamics in Slovenia. To show the effect of changing global oil price dynamics, we analyse a 1 percentage point (p.p.) ex-ante increase in global oil prices. The effects of this shock are displayed in Figure 2, representing the impulse responses of the main macroeconomic variables to the global 
oil price shock. The rise in global oil prices causes oil imports to decline for 0.1 p.p. from the steady state. On the other side the price of oil goods increases for 1 p.p., making the whole economy worse of as the aggregate output, consumption of all type of goods, overall imports, exports, labour and wages decrease. At the same time the inflation increases marginally as it mostly depends on the weight of oil goods in the inflation basket. Comparing the impulse responses of the oil shock to the existing literature, it closely matches the responses to a negative oil shock done by Forni et al. (2015) as they estimated the effect of the oil shock to the euro area economy. The excise duty tax rate on oil products immediately decreases as the government acts counter-cyclically to the dynamics of global oil prices.

Figure 2: Impulse responses of the macroeconomic variables to a 1 p.p. foreign oil price shock (deviations from steady state)
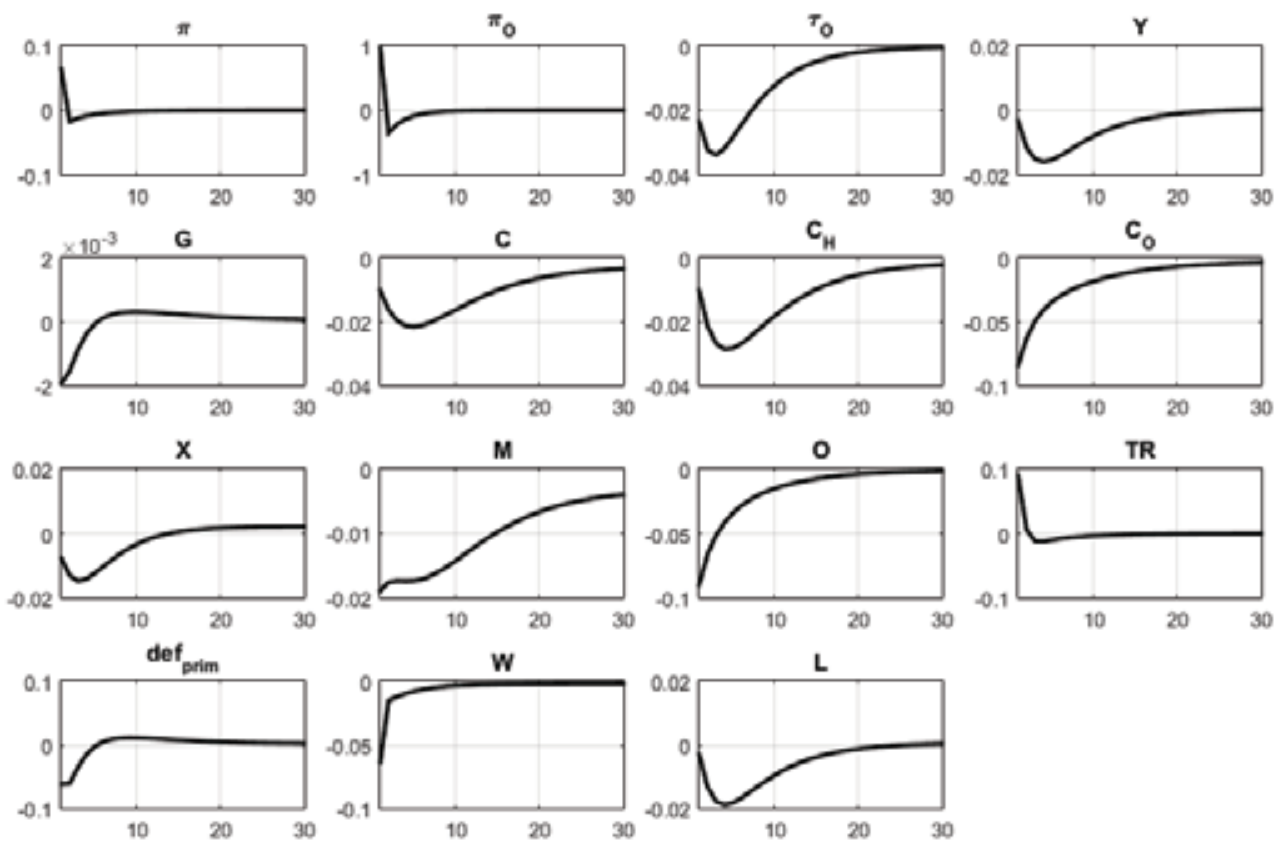

Figure 3 represents the impulse represents the impulse responses of the macroeconomic variables to a 1 p.p. increase of the excise duty tax rate on oil prices. By doing this we show the effects of the government's decision of raising the excise duty tax rate on the economy. As expected the increase in the excise duty tax rate on oil products has similar effects as the global oil price shocks - the cost-push type shocks. The inflation increases, as well as the domestic oil prices. On the other side the aggregate output, consumption, exports, imports, wages and labour decrease. 
Figure 3: Impulse responses of the macroeconomic variables to a 1 p.p. excise duty tax on oil prices shock (deviations from steady state)
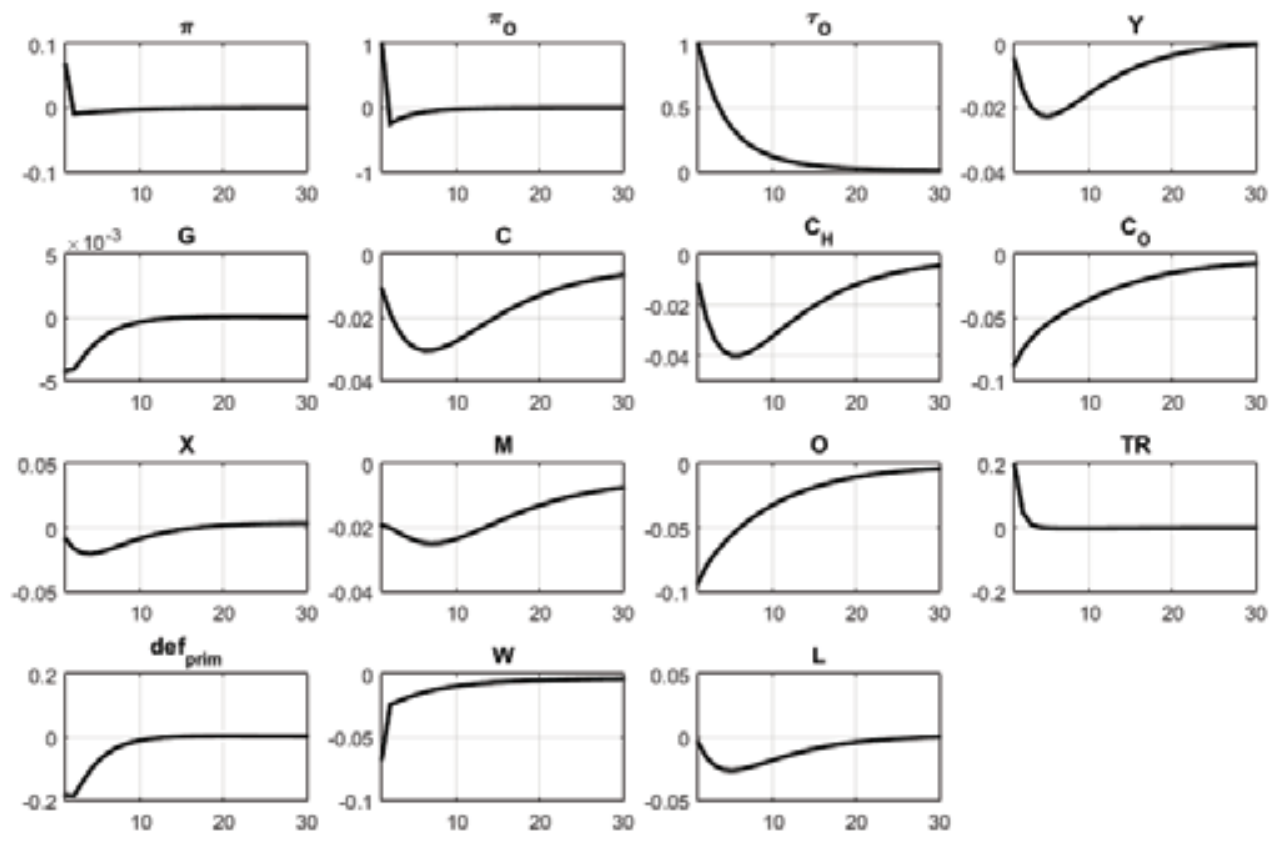

Source: author's calculations

Against this backdrop we provide different scenarios by changing the value of the excise duty tax parameter. Having obtained the estimated values of the model parameters we continue with a comparison of the impulse responses of the main macroeconomic variables by fixing all the parameters to an estimated value and changing the value of the excise duty tax parameter parameter $\gamma_{0}$. The solid line in Figure 4 represents the responses of the variables when $\gamma_{O}$ is set to the estimated value of 0.0964 . The dashed line represents the responses of the variables when $\gamma_{0}$ is calibrated to 0 and the dotted line represents the responses of the variables when $\gamma_{O}$ is calibrated to 1. This way we provide two different calibrated values of the excise duty tax rate parameter $\gamma_{O}$. The distinction of implementing the excise duty tax rule is evident in our case. If an excise duty tax rule is taking place in the economy, the government's fiscal policy is able to steer the increase of global oil prices away from the overall inflation. The harder the government tries to offset the oil price shock, the better it is for the economy inflation-wise. Oil price shocks have less negative effect on real wages and employment of households, since the inflation rises less than in the absence of the counter-cyclical excise duty tax rule. Consequently real consumption of every type decreases less in the case of more aggressive fiscal accommodation of the excise duty tax parameter $\left(\gamma_{O}=1\right)$. The same applies for aggregate real output, exports and im- 
ports. But everything comes at a cost. If the government aggressive enough (i.e. $\gamma_{O}=$ 1), it has to increase its deficit in order to offset the negative oil shocks.

Figure 4: Impulse responses of the inflation variables to a 1 p.p. foreign oil price shock with changing government excise duty parameter (deviations from steady state)
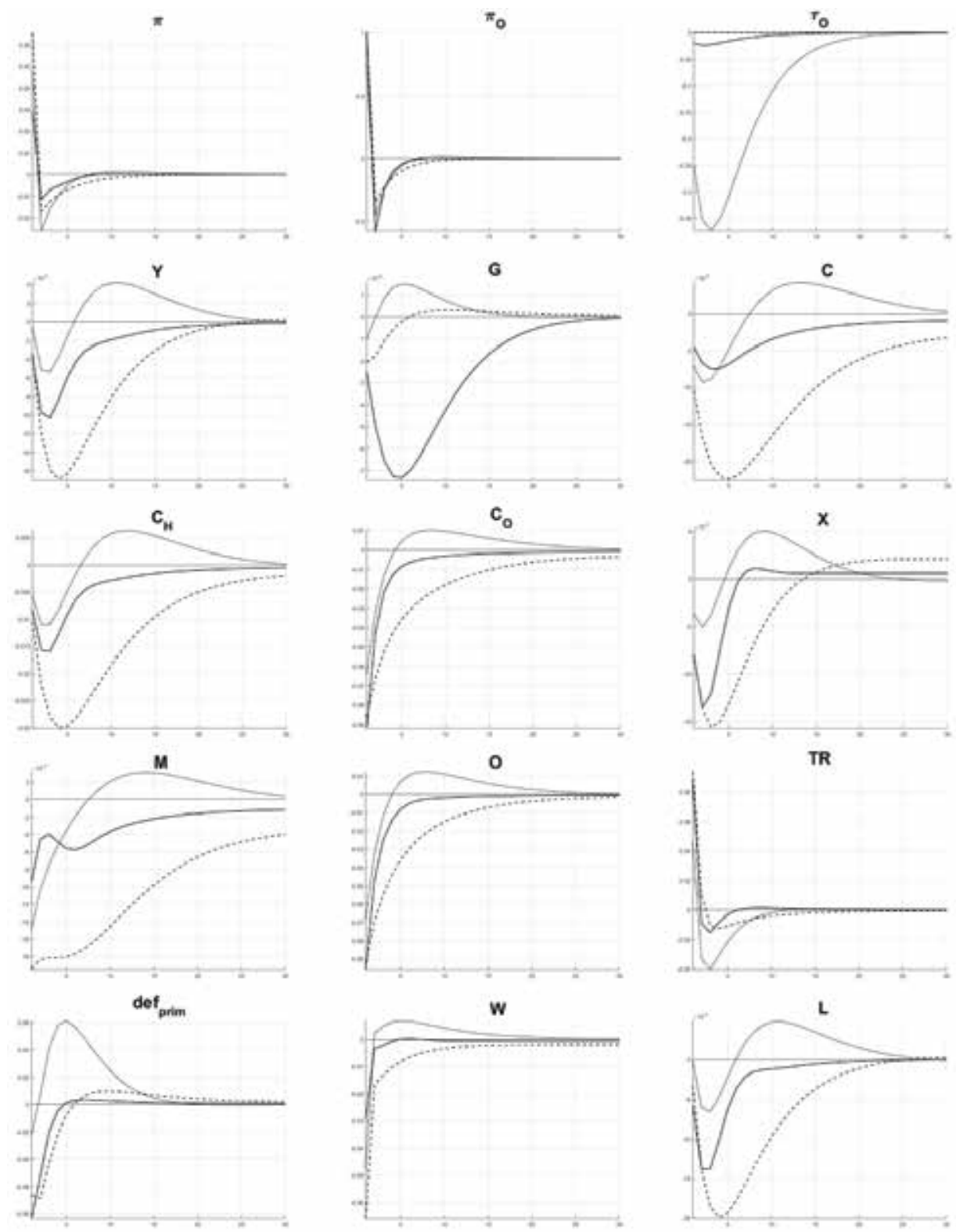

Source: author's calculations 


\section{Conclusion}

In this paper an estimated DSGE model is presented for the Slovene economy. The contribution of the paper is filling the gap by studying the effects of oil shocks on a small open economy model setting integrated in a single monetary union, the euro area, and introducing a concise government sector with excise duty tax rule for oil related products. The structure of the model is set in a typical small open economy fashion, where firms and households are assumed to adjust prices and wages, respectively, à la Calvo. The different composition of the goods bundle allows for the changing demands of different types of goods that are affected by different price setting. By using bayesian inference methodology the key parameters of interest are estimated.

The results show that global oil-price shocks can still have large effects on the Slovene economy. The fiscal policy authority has the power to offset the pressure that the oil price shocks have onto the overall inflation by counter-cyclically regulate the excise duty tax rate on oil products. However, this comes at a cost. Decreased tax income decreases government spending and increases the budget deficit, if the government chooses not to decrease its spending one to one with the decrease in tax income.

\section{NOTES}

1 Excise duty is a tax on consumption. In Slovenia, the system and obligation of paying the excise duty are regulated by the Excise Duty Act which is harmonized with the EU legislation. It was first introduced on July 1st 1999. The excise duty in Slovenia is payable for the following goods released for consumption in the territory of the Republic of Slovenia: alcohol and alcoholic beverages, tobacco products, energy products and electricity (Ministry of Finance, 2016; Ministry of Finance, 2017). The government can act counter-cyclical to the dynamics oil prices and accommodate the level of the excise duties on oil prices in order to decrease the pressure on the overall inflation.

2 All shocks in the model follow an exogenous $A R(1)$ process given by the following representation $\zeta_{t}=\left(1-\rho_{\zeta}\right) \bar{\eta}+\rho_{\zeta} \zeta_{t-1}+\varepsilon_{t}^{\zeta}$, where $\varepsilon_{t}^{\zeta} \sim$ i.i.d., $\left(0, \sigma_{\zeta}^{2}\right)$.

${ }^{3}$ Following Almeida (2009) we set $P_{t}^{\text {num }}=\left(1+\tau_{t}^{C}\right) P_{t}$ as the numeraire for converting nominal variables to real. It is the after tax price of private consumption good.

${ }^{4}$ For simplicity reasons we leave out the exportable commodity good sector, which is defined in Medina and Soto (2005) alongside the foreign demand for home produced good.

${ }^{5}$ Sources: Eurostat, SORS and ECB. 


\section{REFERENCES}

Adolfson, M., Laseén, S., Lindé, J., and Villani, M. (2005). Bayesian Estimation of an Open Economy DSGE Model with Incomplete Pass-Through. Journal of International Economics, 72(2), 481-511.

Almeida, V. (2009). Bayesian Estimation of a DSGE of a DSGE Model for the Portuguese Economy. Banco de Portugal Working Papers 14/2009.

Almeida, V., Castro, G., Mourinho Félix, R., \& Maria, J.S. (2011). Fiscal Consolidation in a Small Euro Area Economy. Banco de Portugal Working Papers 5/2011.

Anzuini, A., Pagano, P., \& Pisani, M. (2012). Macroeconomic Effects of Precautionary Demand for Oil. Banca d'Italia Working Papers no. 918.

Bernanke, B., Gertler, M., \& Watson, M.W. (1997). Systematic Monetary Policy and the Effects of Oil Price Shocks. Brooking Papers on Economic Activity, 28(1), 91-157.

Caldara, D., Cavallo, M., \& Iacoviello, M. (2016). Oil Price Elasticities and Oil Price Fluctuations. International Finance Discussion Papers 1173.

Calvo, G.A. (1983). Staggered Prices in a Utility-Maximizing Framework. Journal of Monetary Economics, 12, 383-398.

Christiano, L.J., Eichenbaum, M., \& Evans, C.E. (2005). Nominal Rigidities and the Dynamic Effects of a Shock to Monetary Policy. Journal of Political Economy, 113(1), 1-45.

Christoffel, K., Coenen, G., \& Warne, A. (2008). The New Area-Wide Model of the Euro Area: a Micro-founded Open-economy Model for Forecasting and Policy Analysis. ECB Working Paper no. 944.

Dixit, A.K., \& Stiglitz, J.E. (1977). A Monopolistic Competition and Optimum Product Diversity. The American Economic Review, 67(3), 297-308.

Erceg, C.J., Henderson, D.W., \& Levin, A.L. (2000). Optimal Policy with Staggered Wage and Price Contracts. Journal of Monetary Economics, 46, 281-313.

Forni, L., Gerali, A., Notarpietro, A., \&. Pisani, M. (2015). Euro Area, Oil and Global Shocks: an Empirical Model-Based Analysis. Journal of Macroeconomics, 46(C), 295-314.

Fourçans, A., \& Vranceanu, R. (2004). The ECB Interest Rate Rule under the Duisenberg Presidency. European Journal of Political Economy, 20(3), 579-595.

Hamilton, J. (1983). Oil and the Macroeconomy since World War II. Journal of Political Economy, 91, 228-248.

Hamilton, J., \& Herrera, A.M. (2004). Oil Shocks and Aggregate Macroeconomic Behavior: The Role of Monetary Policy. Journal of Money, Credit, and Banking, 36(2), 265-286.

Herrera, A.M., \& Pesavento, E. (2007). Oil Price Shocks, Systematic Monetary Policy and 'Great Moderation'. Macroeconomic Dynamics, 13(1), 107-137.

Hongzhi, T. (2010). Effects of Oil Price Shocks on Japan's Economy: A DSGE Approach. International Research Journal of Finance and Economics, 42, 63-73.

Jakab, Z., Baksa, D., \& Benk, S. (2010). Does »The« Fiscal Multiplier Exist?. EcoMod2010 259600082, EcoMod.

Leduc, S., \& Sill, K. (2001). A Quantitative Analysis of Oil Price Shocks, Systematic Monetary Policy and Economic Downturns. Federal Reserve Bank of Philadelphia Working Paper no. 01-09.

Lippi, F., \& Nobili, A. (2009). Oil and the Macroeconomy: a Quantitative Structural Analysis. Banca d'Italia Working Papers no. 704.

Medina, J.P., \& Soto, C. (2005). Oil Shocks and Monetary Policy in an Estimated DSGE Model for a Small Open Economy. Working Papers Central Bank of Chile 353, Central Bank of Chile.

Ministry of Finance. (2016). Excise Duty Act (ZTro-1). Ministry of Finance, Legal Information System. 
Ministry of Finance. (2017). Excise Duty System, Detailed description. Ministry of Finance, Financial Administration of the Republic of Slovenia.

Miyazawa, K. (2009). Estimation of the elasticity of substitution between oil and capital. Economics Bulletin, 29(2), 655-660.

Schmitt-Grohé, S., \& Uribe, M. (2003). Closing Small Open Economies. Journal of International Economics, 61(1), 163-185.

Smets, F., \& Wouters, R. (2003). An estimated Stochastic Dynamic General Equilibrium Model of the Euro Area. Journal of the European Economic Association, 1(5), 1123-1175.

Taylor, J.B. (1993). Discretion versus Policy Rules in Practice. Carnegie-Rochester Conference Series on Public Policy, 39, 195-214. 